Ана В. Римар Симуновић

Универзитет у Новом Саду

Филозофски факултет

Студенткиња докторских студија

ana.rimar@yahoo.com doi: 10.19090/zjik.2018.159-171

UDK 821.161.2 Franko I.

821.161.2(497.11).09 Kovač M.

оригинални научни рад

\title{
РЕЦЕПЦИЈА ИВАНА ФРАНКА У КЊИЖЕВНИМ ДЕЛИМА МИХАЈЛА КОВАЧА*
}

САЖЕТАК: У овом раду се анализира рецепција Ивана Франка у делима Михајла Ковача. Иван Франко (1856-1916) је класик украјинске књижевности, а Михајло Ковач (1909-2005) је русински писац који је своје књижевно дело формирао на традицији украјинских класика, али никад није био писац епигон. Пошто је опус оба писца веома обиман, а обојица су писала поезију, прозу и драму, у овом раду сам одабрала по једно дело из поезије, прозе и драме Ивана Франка и приказала рецепцију тих дела у делима Михајла Ковача.

Кључне речи: Иван Франко, Михајло Ковач, рецепција, русинска књижевност, украјинска књижевност

Михајло Ковач је русински писац који је своје књижевно дело започео прозом, десетак година касније је написао прву песму, а писао је и драме, као и књижевна дела за децу. Ковач наставља традицију класика украјинске књижевности. Он је читао многе писце, иако није увек био свестан књижевних конвенција дела која је читао. Говорио је да највише воли да чита оне писце које је могао да разуме и осећа, као и оне који су били блиски његовом животном и књижевном искуству. Иако Ковач наставља традицију украјинских писаца, он није писац епигон, јер све што је примио од других писаца прилагодио је тако да би га Русини у Војводини могли разумети. То значи да је мотиве и теме које је обрађивао у својим делима, а која је преузео од других писаца, прилагодио животном искуству својих сународника на овим

\footnotetext{
Овај рад је саопштен на научном скупу поводом 160-годишњице рођења Ивана Франка. Међународни научни скуп је одржан од 22. до 24. септембра 2016. године на Лавовском националном универзитету „Иван Франко” у Украјини.

Рад је написан у оквиру пројекта „Дискурси мањинских језика, књижевности и култура у југоисточној и средњој Европи” бр. 178017, који финансира Министарство просвете, науке и технолошког развоја Републике Србије.
} 
просторима. У овом раду сам анализирала и приказала рецепцију појединих дела из поезије, прозе и драме Ивана Франка у делима из поезије, прозе и драме Михајла Ковача. О овој теми није писано много, али је Јулијан Тамаш у својој књизи Свангелиста Михайло Ковач (Јеванђелиста Михајло Ковач) (Тамаш 2009) анализирао рецепцију украјинских, југословенских и писаца из светске књижевности у Ковачевим делима, тако да је у њој представљен однос између Франкове драме Украдзене щесие (Украдена срећа) и Ковачеве драме Суд правди (Суд истине). Тамаш је само у најкраћим цртама указао на релацију ова два писца, а ја сам у овом раду то разрадила. Нема објављених научних радова о односу између поезије и прозе ова два писца. Од изузетног значаја за овај рад били су дневници које је Ковач водио, а које сам добила на коришћење од Олге Карлаварис, његове кћери.

Прву приповетку Михајло Ковач објавио је 1927. године, тек двадесетак година након што је 1904. године објављен Идилски венєи „3 мойого валала” (Идилични венач „Из мог села”) Хавријила Костељника, књига којом почиње живот русинска књижевност на простору данашње Војводине. У то време русинска интелигенција се окупља у оквиру Русинског народног просветног друштва (РНПД) тако да је и Михајло Ковач своја прва књижевна дела објављивао у издањима овог друштва.

Формирањем Русинског народног просветног друштва Просвета (РНПД Просвита) 2. августа 1919. године у сали магистрата у Новом Саду постављене су основе за развој образовања, науке и културе југословенских Русина (Тамаш 1984: 81).

Осим Ковача и Костељника, тада је у русинској књижевности био присутан веома мали број писаца.

Русини су се средином 18. века на просторе данашње Војводине доселили, између осталог, и са простора Закарпатја, тако да од тада до данас, с повременим прекидима и разлици у интензитету, трају књижевни и културни контакти између тог простора и Русина у данашњој Војводини.

Свака појава у књижевности југословенских Русина мора се проучавати најмање у четири контекста: изворном, контексту југословенских књижевности, закарпатске и украјинске књижевности (Тамаш, 1984:19). 
Тамаш је у књизи Историја русинске књижевности (1997) прикључио и пети контекст, контекст светске књижевности.

Контекстом украјинске књижевности успостављамо ону студијску ситуацију која нам омогућује да проучавамо меру и видове рецепције писаца украјинског језика у књижевности на русинском језику у Југославији (Тамаш 1984:19).

Михајло Ковач је русински језик сматрао за дијалекат украјинског језика, Русине у Војводини је видео као украјинску дијаспору, а русинску књижевност као део украјинске књижевности. Пошто је био учитељ, а у ситуацији да без буквара и основних уџбеника треба да организује наставу, био је практично приморан да састави књиге неопходне за наставу. Књиге на које се угледао су биле управо уџбеници и буквари који су на ове просторе стизали са простора данашње Украјине, тако да се преко њих упознао са делима из украјинске књижевности. Осим тога што је био учитељ, а био је учитељ у многим местима, био је и преводилац и истакнут културни радник у сваком месту у ком је радио, тако да је организовао, а често и водио разне секције: драмске, хорске, рецитаторске, фолклорне. За потребе драмске секције је често на русински језик преводио украјинске драме, а кад је видео да је за потребе драмских секција у русинским културно-уметничким друштвима потребно да изводе и драме написане на русинском језику, и сам је почео да их пише.

Ковач је отворено говорио о томе које је писце читао и који су га писци инспирисали у његовом књижевном раду. О томе је говорио у разним интервјуима за новине и часописе, а водио је и дневнике лектира у које је записивао имена писаца, називе њихових дела, као и размишљања на која су га та дела подстакла. За потребе овог, али и других радова, успела сам да дођем до десет таквих дневника Михајла Ковача. Он је веома уредно водио своје дневнике. У њима је детаљно записивао ствари из приватног живота, пословног планирања, а записивао је готово свакодневно планирање и организовање времена. Детаљно је записивао и сакупљао све што је о њему или о његовим делима негде објављено. Такође, записивао је имена писаца и називе њихових дела која је читао, као и своја размишљања о прочитаном. У дневницима је писао да свакодневно мора да чита и пише, а док чита друге писце, да обавезно то ради с оловком и папиром у руци, и да записује шта би од тога могао да искористи у својим делима. Један од дневника је назвао 
Лектира и литература (1961-1976) $)^{1}$ и из тог дневника се може видети да је читао класике украјинске књижевности. За овај рад је од посебног значаја то што Михајло Ковач у том дневнику навео да је читао приповетке Ивана Франка. Од тих приповедака четири су се нашле у књизи Вибрани твори (Изабрана дела) Ивана Франка која је објављена 1966. године, а за коју је избор и превод урадио управо Михајло Ковач. У овом раду ћу пажњу посветити једној од тих приповедака због тога што су у њој обрађене теме и мотиви које је Ковач обрадио у многим својим приповетка. Реч је о приповеци Лесихова челядз (Лесишина чељад). Ковач је, као закључак на основу прочитаних неколико Франкових приповедака у свој дневник, записао следеће:

У делима Ивана Франка нема шта да се истражује, досмишљава, сумња... Све је јасно: зло се хвата тамо где има погодну атмосферу. Људи од тога трпе, пропадају. Због тога је жао праведном човеку, али то не треба да остане на жалости. Треба изазвати гнев, мржњу, како би људи потражили корене зла ***2 . А корени зла су: експлоататори, ***.

У предговору Изабраним делима ${ }^{3}$ Ивана Франка, Михајло Ковач је објаснио због чега је одлучено да се дела Ивана Франка написана на украјинском књижевном језику преведу и објаве на русинском језику:

Хтели бисмо да кажемо неколико речи о Ивану Франку из нашег аспекта, из аспекта нас Русина, јер је тај велики човек, - велик не само у оквиру украјинског народа, него у оквиру такорећи, целог човечанства, - јако добро познавао наше услове, био нам је пријатељ, учитељ и руководилац у временима када осим Кузмјака, Врабеља и Костелника готово никог нисмо имали (Франко 1966:7).

Он је био свестан да је утицај српског језика на русински веома јак па је један од разлога због којих се одлучио на превођење, управо тај да би се на овај начин покушало вратити русински језик својим изворима од којих је дуго одвојен. На тај начин је желео да обогати русинску лексику и развије русински језик. Такође, желео је да приближи део стваралаштва Ивана Франка Русинима

\footnotetext{
${ }^{1}$ Михајло Ковач је овај дневник писао на русинском језику. Делове текста које ћу наводити у овом раду, превела сам са русинског језика на српски.

2 Звездицама су означена места која не могу да се прочитају због веома ситног и, на тим местима, нечитког рукописа.

${ }^{3}$ Књига Вибрани твори (Изабрана дела) објављена је на русинском, па сам за потребе овог рада, делове текста које наводим, превела на српски језик.
} 
у Војводини, како би се заинтересовали за њега, потражили његова дела на украјинском језику, па и освестили националну припадност.

Иако је Ковач рекао да није бирао Франкова дела према неким одређеним критеријумима, може се закључити како је изабрао дела из његовог опуса:

Ми смо просто покушали да пратимо писца од куће његовог оца кроз амбијент села, места, амбијент радника на њиви, или тамо у рупама где се вадила нафта, или пак кроз амбијент затвора у ком је и сам писац неколико пута био због својих ставова (Франко 1966: 10).

Управо је ово први моменат на основу којег може да се закључи да постоји веза између Франкових и Ковачевих дела.

Франко се у свом обимном опусу више пута окретао сеоској проблематици. Сам пореклом са села, син имућног сеоског ковача који рано напушта своју средину, дубоко спознавши психологију сељака, он настоји да дочара терет њиховог живота на начин на који би се у огледалу индивидуалне психологије разоткрили разлози индивидуалних и колективних недаћа (Поповић 2007: 101).

Ковач је, такође, инспирацију за своја дела тражио у селима, међу сеоским људима и њиховим судбинама. Оно што је наведено из закључка, као и објашњење из предговора, кључне су ствари да би се схватила рецепција дела Ивана Франка у Ковачевим делима. Сам Ковач је говорио да многа његова дела не могу да се сврстају у одређен чист књижевни жанр и да то треба увек имати на уму кад је о његовом стваралаштву реч. Такође, говорио је да највише воли кад га свет прима као приповедача.

Приповетка Лесишина чељад Ивана Франка почиње описом природе и буђењем дана у сеоском амбијенту и тиме уводи читаоце у живот традиционалне сеоске пољопривредне породице где живи више генерација. У овом случају, то су стара Лесиха, њена кћи, син и невеста и двојица слуга. Међу њима је веома изражена непрестана свађа, односно Лесишино незадовољство млађим члановима породице и њиховим начином рада на њиви. Посебно је незадовољна ћерком и невестом. Незадовољна је и младићем с којим се виђа њена кћи, због тога што није довољно имућан. Лесишин син дуго није могао да се ожени, а кад се оженио, Лесиха није била задовољна његовим избором, пошто је невеста била веома сиромашна. За њеног сина Хната важан је моменат описа 
разлога због којих се дуго није могао оженити. То је због тога што је по селу почело да се прича да уме да украде и да је помало зао. Оно што означава Лесиху као неког чија је судбина заиста трагична јесте чињеница што јој је муж умро, а она је после његове смрти с времена на време пробала да пронађе утеху у алкохолу. Увек је пила сама и никад није дошла у ситуацију да мора да продаје капитал због алкохола.

Ковач је у својој прози сликар традиционалне русинске породице на селу. У његовим делима је изражен однос према природи и веома често и Ковач у причу уводи управо описом природе. Природа је непрестани пратилац свега што се дешава у његовим делима. И Франко и Ковач веома често у средиште својих прозних дела, а Ковач и у целокупно своје стваралаштво, стављају раднике односно сељаке, дакле оне који највише раде, а од чијег рада живе они на власти. Сукоб међу генерацијама је свуда присутан, само што у зависности од друштвене средине има различите последице. У приповеци Лесишина чељад сукоб међу генерацијама је начин живота, док је Ковач овај мотив разрадио много дубље. У његовим делима сукоб међу генерацијама често води ишчезавању једног народа. У поменутој Франковој приповеци назире се мотив трагичне љубави Лесишине кћери и момка којег воли, али није по вољи њене мајке. У оквиру међуратних приповедака Ковач има цео типолошки круг приповедака о ускраћеној трагичној љубави, а међу послератним приповеткама је и типолошки круг о сукобу „очева и синова”. Сукоб међу њима настаје због јаза међу генерацијама, различитог погледа на свет, али и због онога што је Ковачу најтеже да прихвати: слабији осећај припадности деце свом народу, месту где су рођени а, заједно с тим, и традицији и култури које су наследили од својих родитеља. Видимо да је Ковач разрадио мотив сукоба до тога да тиме на неки начин образује и освешћује свој народ. Овај мотив је посебно изражен у приповеткама Розиходзеня (Растанци), Миколов святочни дзень (Миколин свечани дан), Празне гнїздо (Празно гнездо). Овим приповеткама је заједничко што деца у њима немају осећај припадности свом народу, а изабрали су себи животног сапутника који није по вољи њиховим родитељима.

Лесишин син Хнат представљен је као неко о коме се у селу прича у негативном контексту, јер је умео да украде. Иако код Франка ово није моменат на коме је изграђена приповетка, када је реч о рецепцији његовог дела у Ковачевом књижевном стваралаштву, занимљиво је што је Ковач преко својих дела настојао да искорени негативне особине и негативне људске нарави. Ковачев реализам је поетски реализам, што значи да у својим делима није 
остајао по страни као неко ко само прати догађаје, него се веома јасно види ком лику је наклоњен. Готово сваку приповетку је завршавао закључком у којем је читаоцима обраћао пажњу на то које људске нарави нису добре и због чега их треба искоренити, и на тај начин је постао народни учитељ.

Лесишина судбина љубави је трагична, муж јој је умро па је почела да пије. Ковач је и тај мотив разрадио у својим делима, посебно у приповеци Селянска шмери (Сељачка смрт). У овој приповеци сељак се жени по други пут због смрти прве супруге. Никако не може да је прежали, почиње да пије и пропада. Ковач је увек на страни праве љубави, а сви његови ликови којима је права љубав из неког разлога ускраћена, пропадају као личности.

У Дневнику 1966-1969 на 699. страни на месту где је записао шта је тог дана прочитао, Ковач је написао и следеће: „І. Франко: Каменярі”. У предговору Изабраних дела Ковач је за Франка рекао да је каменоломац. Ово не можемо разумети без познавања Франкове песме под тим насловом. На основу песме Каменоломщи може да се прикаже рецепција Ивана Франка у поезији Михајла Ковача, али и његовом делу уопште.

Каменоломци представљају клесаче камена. Песму можемо схватити као песму провидног значења где каменоломци уништавају стену, дакле нешто што је веома јако и пружа отпор. Истовремено се тим уништавањем даје основа за настајање и обликовање нечег новог (од камена се могу направити путеви, куће...). Међутим, ако се дубље продре у смисао и узме у обзир време у коме је настала песма (1878. године) и да је то време преласка из феудализма у капитализам, схватамо да је ово алегоријска, револуционарна песма. „Лик камењара који са чекићем у руци разбија стену и гради нови, чврсти пут, симбол рада и радничке класе, основни је семантем у Франковој револуционарној поезији” (Татаš 1977:25). Треба напоменути и да је у овој песми извршена потпуна идентификација лирског субјекта (ја) са народом (ми). „Храст је увек и свугде синоним снаге: тај утисак очигледно оставља одрасло стабло. Симболизује једнаку моралну и физичку снагу" (Gerbran-Ševalije 2013: 279). Ако ову песму схватимо као песму веома јасног значења, лако је повући паралелу са целокупном поезијом Михајла Ковача јер је она увек таква - јасна. Али ако је схватимо као алегоријску песму, јасно се види шта је Ковач из ове песме „уградио” у своју песму Я дуб червоточни (Ја сам храст ирвоточан). То је песма у којој се песник, лирски субјект поистовећује са храстом, али храстом који је црвоточан. Песма говори о томе да ће тај храст једном, ко зна кад, иако 
као храст представља нешто веома снажно и чврсто, ипак подлећи зубу времена. Дакле, прети му црвоточ који ће га уништити. Па ипак, песнику остаје нада да ће бити неке користи од његовог толиког труда. Мисли се на труд који је уложио у књижевни и свој целокупан рад са народом и за народ. Нада се да ће се људи барем од његових грана, кад стисне зима, огрејати руке, а можда и срца. Треба напоменути да је аутор у тренутку настајања песме (1976. године) имао скоро седамдесет година, а иза себе готово педесет година књижевног стваралачког рада. И Франко и Ковач у наведеним песмама афирмишу служење народу, с тим што је Франко социјални револуционар, а Ковачева пажња усмерена је на моралне хришћанске императиве који су основа целокупног његовог књижевног стваралаштва, не само поезије. Преко својих дела, која је градио на развијању емпатија према моралним и поштеним људима, Ковач је постао на неки начин народни проповедник и учитељ. Франко је у овој песми на страни правде за раднички слој људи, а Ковач је, такође, у својим делима увек на страни оних који највише раде. Међутим, Ковач не иде тако далеко као Франко, његови јунаци не устају против власти, иако се и у Ковачевим делима сусрећемо са приказивањем стварних друштвених односа и угњетавањем сељака. Ковачеви ликови су свесни те неправде, али та неправда остаје на нивоу индивидуалног незадовољства.

Иван Франко је веровао у велику друштвену моћ поезије. Њену мисију видео је, пре свега, у моралном уздизању човека, односно у замени нехуманог социјалног поретка хуманим међуљудским односима. Зато је између њене суштине и морала стављао знак једнакости (Хајдуковић 1999: 66).

За Ковача такође важи све наведено, с тим што је он у целокупном књижевном стваралаштву видео мисију моралног уздизања човека.

Франко је, као и Ковач, писао и драме. Франкова драма сеоског живота Украдзене щесце (Украдена срећа) састављена је од пет чинова, а Ковачева драма Суд правди (Суд правде) драма је из народног живота, такође састављена од пет чинова. Осим тога, простор и време драме готово су исти, тако да, ако знамо да је управо Ковач превео ову Франкову драму на русински језик и да налазимо толико сличности и у његовој драми, јасно је да се ради о рецепцији Франкове драме. Украдена срећа је драма која се дешава око 1870. године у селу Незваничи у Украјини. Ковач није написао тачно време и конкретно село у коме се одржава радња, већ само да се дешава у једном сремском селу крајем 19. века, 
тако да је драму приближио и прилагодио Русинима на овим просторима. За Ковача је карактеристична репрезентативност ликова, тако да се то односи и на овај случај. Радња је могла да се догоди у било ком селу у ком су живели Русини у то време. Ове две драме имају заједнички фокус интересовања, који приказује какво је стање у селима, какви су животни услови, друштвени односи, жеља за имовином и људске нарави. Реч је о типичном селу у којем живе Русини, његови становници су углавном пољопривредници. С друге стране, Незваничи су планинско село, зиме су јаке, има пуно снега, мушкарци одлазе да секу дрва у шуму и од тога живе. То је сељацима и најтежи део године, јер такве услове није лако издржати. Посебно ако им велики део зараде узима власт. Такав је живот и код Русина на овим просторима, па је то представљено у Ковачевој драми. Услови за живот су такође тешки, а Ковач је изабрао лето као време у којем се дешава драма, јер је тада сељацима најтеже и имају највише посла.

У драми Украдена срећа реч је о Ани која се против своје воље удала за Миколу, човека који је од ње старији двадесет година. Удала се за њега на силу јер су јој њена рођена браћа рекла да је Михајло, човек којег је волела, умро. То није била истина, али су се браћа плашила да ће им он узети њен мираз. Ана није срећна с Миколом, али се већ навикла на такав живот. После неког времена Михајло се вратио у село, сада на функцији жандара, и искористио је своју позицију како би постигао своје циљеве. Ухапсио је Миколу да би могао да буде с Аном, а на крају га је управо Микола убио. Овај моменат је кључан за повезивање поменутих драма Франка и Ковача. И у једној и у другој драми се поставља морално питање о томе да, ако је неко дошао до среће преко туђе несреће, да ли је морално неоправдано узети од њега ту срећу до које је дошао на непоштен начин.

У Ковачевој драми, у фокусу је љубавна прича о Михајлу, сиромашном младићу, и Ирине, богате девојке. Они желе да се узму, али њени родитељи не желе да се њихова кћи уда за сиромашног младића. Он због тога одлази у Америку надајући се да ће тамо наћи бољи живот. Борба за бољим животом га доводи у ситуацију да не зна шта ће бити с његовом љубављу кад се врати: да ли ће га чекати као што му је обећала на растанку или ће се удати за другог. Ирина је у јака у својој одлуци да ће чекати драгог, али се у то умешао Петар, син човека који је био на челу сеоске власти. У то је умешао и Јанка и уцењује га да ће девојка коју овај воли - Меланија, бити његова ако му он помогне да дође до Ирине. Петар је искористио прилику што је случајно био с поштаром кад је од Михајла стигло писмо из Америке у којем каже да ће се ускоро вратити. 
Искористио је и то што је поштар био под дејством алкохола, узео је од њега писмо, написао ново у којем је саопштено да је Михајло умро и однео то писмо Михајловом оцу који, чувши вест, на месту умире. Ирина, пошто је сазнала вести, морала је да пристане да се уда за Петра. Тада се дешава нешто неочекивано, Михајло се уочи свадбе враћа у село и Ирина је одмах отишла с њим. Петру је сад већ била добра и Меланија, па је њу оженио. На њихову свадбу је дошао и Јанко, момак који је волео Меланију и убио Петра. На крају обе драме се дешава убиство, убијају они који су на непоштен начин желели да дођу до среће. „Обема драмама је заједничко што главни ликови желе да узму сопствену судбину у своје руке, што, сагласно библијској теологији, Бог, или живот сам, казни" (Тамаш 2009: 199).

На основу тога можемо направити паралелу између ликова у Франковој и Ковачевој драми. То су ликови Михајла Хурмана - жандара и Петра, Михајла и Миколе и женски ликови - Ане и Ирине.

Михајло Хурман и Петро су представници оних који желе преко туђе несреће да дођу до сопствене среће. Михајло то ради у драми Украдена срећа, а Петро у драми Суд правде. Жандар се меша у туђ брак и уништава га, а Петро у везу која је требало да прерасте у брак, али њему се планови нису остварили. Иако је Ковач сачувао достојанство брака, Франковог Михајла и Ковачевог Петра повезује то што је њихов пут до среће морално неприхватљив. У тренутку кад уништавају туђу везу односно брак, обојица су на власти или су власти блиски. То им даје статус на основу којег су на вишој позицији у односу на друге сељаке. Они представљају све оне који су на власти и којих има у готово сваком друштву. Они своју позицију користе како би постигли своје циљеве, што такође није морално. На овај начин су оба писца показала какво је стање у друштву и да је власт много пута јача од правде. Тиме су приказани и друштвени односи, а за повезивање ове две драме је важно што су такви односи представљени и у Незваничима и у сремском селу.

Ни Михајло ни Петар не поштују Бога, чак га и омаловажавају. Обојица су себични, егоисти. Мото њиховог живота је да „циљ оправдава средства”. Жандар уништава Анин брак, њеног мужа хапси тако што говори лажи о њему. После тога се јавно виђа с њом, без трунке срамоте. Петар је такође човек кога није срамота, а не гризе га савест ни онда када је Михајлов отац умро због његове лажи. Из овога можемо да видимо једно од Ковачевих схватања света, а 
то је да нисмо морално изгубљени све док нас је срамота због непоштених ствари које радимо.

Михајло и Микола су жртве оних који су на непоштен начин хтели да дођу до среће. Микола није крив што Ана није задовољна у браку, она воли жандара. Жандар је ухапсио Миколу који верује да је то божја воља. Он је и жртва своје жене која га није посетила у затвору већ се за то време виђала са жандаром. Кад је изашао из затвора, видео је своју жену са жандаром у крчми. Овако је реаговао: „Нека теби бог плати за све добро, а за зло... (гледа с прекором у Ану), зло нека вам не памти.”

Из овога можемо да закључимо да је Микола хришћанин који прихвата божју вољу, а Ану не осуђује. Међутим, почео је да пије, а на крају се посвађао са жандаром, па га је и убио. Михајло, сиромашни младић у драми Суд правде сличног је карактера као Микола. Побожан је и такође верује да се све дешава према божјој вољи. Кад је одлазио у Америку, Ирини је рекао следеће: „Не, удај се ти... Родитеље мораш да слушаш... Таква је божја заповест...” Из овога такође можемо да закључимо да је, као и Микола, и Михајло хришћанин коме су јако важне божје заповести.

Михајло је Петрова жртва јер му је он узео Ирину, а у то је умешао и Јанка. Кад се Михајло вратио из Америке, затекао је дом без оца, а Ирину спремну за свадбу с Петром. У истом тренутку је остао без својих најдражих, за шта је крив Петар који му је узео срећу да би дошао до своје среће. Међутим, Ковач није дозволио да неправда превлада, тако да се Ирина ипак удала за оног којег воли, за Михајла. Управо је ово најзначајнији моменат на основу којег можемо да докажемо рецепцију Франкове драме у драми Михајла Ковача. И у једној и у другој драми се такође догађа убиство онога који је хтео да дође до среће преко туђе несреће.

Ана и Ирина су главни женски ликови и међу њима такође можемо да повучемо паралелу. Ана је трагичан лик у драми Украдена срећа, а Ирина у драми Суд правде. Заједничко им је што нису могле својом вољом да изаберу супружника, већ су то урадиле њихове породице, а основни критеријум им је било имовинско стање. Ни једна ни друга не могу да реализују љубав са човеком којег воле јер је жеља њихове породице за имовином јача од жеље да њихова кћи буде срећна. Обе су пристале да се удају за другог тек кад су сазнале да је њихов драги умро. Обе су због тога несрећне, али Ана је трагичнији лик, јер она ступа у брак са човеком којег не воли. Ковач је желео да сачува чисту 
љубав па је Ирину сачувао од брака са човеком којег не воли. Ана, иако је била у браку, није била верна свом мужу, али се није стидела због тога. Ирина се такође није стидела да оде са човеком којег воли, иако је свадба са другим већ била припремљена. Разлика између њих две је у томе што је Ана у својој љубави неморална, прекршила је божје законе, а Ирина још увек није ступила у брак, па нема због чега да је гризе савест. Управо због тога Анина срећа не траје дуго. И она је на непоштен начин, тј. преко несреће свог мужа хтела да дође до своје среће. Ирина је у својој љубави чиста и њена срећа траје дуго.

Пошто су обе драме о тешким животним судбинама, писцима је било потребно олакшати их нечим што показује да је то прави живот на селу. Франко је због тога искористио елементе мелодраме. То су тренуци у којима су млади у улози хора, кад певају и играју у крчми. Они показују лепшу страну живота. Ковач је то искористио, па је те елементе такође уградио у своју драму. И код њега млади певају на прелу и на улицама.

У драми нема много могућности за ауторове коментаре онога што се дешава, па су Франко и Ковач ту улогу доделили младим и сеоским женама. Млади сажаљевају Ирину због тога што је родитељи наговарају да се уда за Петра, млади подржавају правду и моралне законе. Тако је у Франковој драми у тренутку кад коментаришу да није у реду да Ана и жандар играју заједно у крчми, па због тога и они престају да играју и певају. Сеоске жене су и у једној и у другој драми оне које знају све што се у селу дешава. Оне саопштавају истину или тајне које јавност није смела да сазна.

И у Франковој и у Ковачевој драми, срећа стечена на туђој несрећи није дугог века. Разлика међу њима је што је Ковач сачувао достојанство породице и чисте љубави.

Овим радом није завршена анализа рецепције Франковог опуса код Ковача. Остаје отворено питање повезивање осталих дела из поезије једног и другог писца где треба обратити посебну пажњу на однос према природи, исказивање љубави према жени, афирмацију рада као смисла човековог постојања, изражавање родољубља. Што се тиче прозе и драме, и на том пољу постоји још простора за даља истраживања.

Но, на основу оног што је у овом раду анализирано, види се да је дело Ивана Франка у великој мери обележило и формирало целокупно дело Михајла Ковача, о чему је и сам Ковач говорио, јер је Франка сматрао за једног од својих 
претходника, поред Тараса Шевченка, Лесје Украјинке, Васиља Стефаника и других великих писаца украјинске књижевности.

\section{ИЗВОРИ}

Ковач, Михайло. 1989. Я дуб червоточни. Нови Сад: Руске слово.

Ковач, Михайло. 2003. На швитаню, вибрани драми. Нови Сад: Руске слово.

Франко Иван. 1966. Вибрани твори. Нови Сад: Руске слово.

Шевченко, Тарас и др. 1999. Хучи Дюепар широки. Београд: Завод за уџбенике и наставна средства.

\section{ЛИТЕРАТУРА}

Поповић, Људмила. 2007. Фокусна перспектива украјинске књижевности. Београд: Филолошки факултет.

Тамаш, Јулијан. 1984. Русинска књижевност. Нови Сад: Матица српска. Тамаш, Юлиян. 2009. Євангелиста Михайло Ковач. Нови Сад: Руске слово. Tamaš, Julijan. 1977. Između književne teorije i interpretacije. Novi Sad: OOUR. Gerbran, Alen, i Ševalije, Žan. 2013. Rečnik simbola. Novi Sad: Stylos art: Kiša.

Ana V. Rimar Simunović

THE RECEPTION OF IVAN FRANKO IN MIHAJLO KOVAČ'S LITERARY WORKS

Summary

This paper analyses the reception of Ivan Franko in Mihajlo Kovač's literary works. The literatry opus of Mihajlo Kovač had been heavily influenced by classics of the Ukrainian literature. Among those whose influence of Kovač's literatury work is analysed is Ivan Franko. In order to analyse the reception and draw parallels between Ivan Franko and Mihajlo Kovač, one poem, one story and one play by the aforementioned Ukrainian writer have been used. These two writers are connected to each other by the village area and the description of hard life of the peasants. They are also connected to each other by the conflict between the generations, particularly between parents and children, that we can read about in Kovač's and Franko's stories. Connected to this is the social and analytical function as the stabilizing of the nation, in Kovač's literary works. This paper represents the first step of the systematic analyses of the reception of Ivan Franko in Mihajlo Kovač's literary work.

Key words: Ivan Franko, Mihajlo Kovač, reception, Ruthenian literature, Ukrainian literature 
